\title{
PELATIHAN TANAMAN VERTIKAL DI KOTA MANADO
}

\author{
Michael M. Rengkung, Windy Mononimbar, \& Ingerid Lidia Moniaga \\ Laboratorium Bentang Alam, Program Studi Perencanaan Wilayah dan Kota, Fakultas Teknik, \\ Universitas Sam Ratulangi (UNSRAT) \\ mmichaelreng@gmail.com; wmononimbar@yahoo.com; ingeridmoniaga73@gmail.com
}

\begin{abstract}
Abstrak
Kecamatan Tuminting merupakan salah satu kecamatan yang berada di Kota Manado yang memiliki lingkungan permukiman penduduk dengan lahan terbatas untuk dikembangkan sebagai ruang terbuka hijau (RTH). Dengan keterbatasan lahan pada lingkungan permukiman tersebut maka tim IbM hendak mengusulkan pengembangan RTH lingkungan perkotaan melalui penerapan konsep taman vertikal pada lahan-lahan sempit melalui kelompok Karang Taruna Kecamatan Tuminting yang aktif dan peduli dengan program-program peningkatan lingkungan hijau yang bersih, sehat dan asri.

Tujuan pelaksanaan kegiatan Pengabdian Kepada Masyarakat ini, yaitu memberi pembinaan dan pendampingan pada kelompok Karang Taruna melalui Pelatihan Taman Vertikal di Kota Manado sebagai upaya penghijauan pada lahan terbatas perkotaan.

Target luaran yang ingin dicapai pada pembinaan dan pendampingan kelompok Karang Taruna Kecamatan Tuminting Kota Manado adalah (1) meningkatnya pengetahuan masyarakat dalam menciptakan RTH private melalui pengembangan taman vertikal, (2) memahami dan melakukan kegiatan praktek taman vertikal, (3) memiliki kemampuan mengelola lahan perkotaan yang terbatas melalui penerapan taman vertikal, (4) terciptanya kualitas lingkungan indah perkotaan, (5) menghasilkan artikel ilmiah yang dapat dipublikasikan pada seminar nasional.
\end{abstract}

Kata Kunci: Taman vertikal, ruang terbuka hijau.

\section{PENDAHULUAN}

\section{Analisis Situasi}

Ruang terbuka hijau adalah ruangruang terbuka yang diisi oleh tumbuhan atau tanaman baik yang berbentuk memanjang atau linear maupun berbentuk mengelompok yang berfungsi untuk menciptakan kesan alami, indah, menarik dan estetis. Ruang terbuka tidak hanya berfungsi ekologis sebagai resapan air, memproduksi oksigen (02), pembentuk iklim mikro perkotaan, ameliorasi iklim, dan lainnya tetapi juga sebagai unsur pembentuk keindahan lingkungan perkotaan. Keterbatasan dan tingginya lahan perkotaan memunculkan persoalan berkurang dan hilangnya ruang-ruang terbuka alami. Salah satu upaya meningkatkan kualitas lingkungan perkotaan yakni dengan mengembangkan ruang terbuka hijau melalui konsep taman vertikal (vertical garden). Vertical garden atau taman vertikal adalah sebuah konsep taman tegak atau vertikal dengan mengatur tanaman dan elemen taman lainnya sedemikian rupa pada sebuah bidang tegak. Konsep taman vertikal merupakan sebuah upaya untuk menghjaukan sebuah tempat yang terbatas dimana tempat tersebut tidak memungkinkan untuk dibuat taman hori-zontal. Taman vertikal mulai banyak dikem-bangkan di kota-kota besar di Indonesia sebagai upaya mengatasi keterbatasan lahan di perkotaan. Dengan lahan yang terbatas, maka konsep taman vertikal sangat sesuai diterapkan dan dikembangkan pada tembok rumah, dinding atau pagar serta bidang tegak lainnya seba- 
gai area taman. Konsep taman vertikal di Kota Manado tahun 2017 mulai dikembangkan pada bidang-bidang tegak persimpangan-persimpangan jalan umum. Namun di lingkungan permukiman yang sempit dan terbatas lahannya masih belum diterapkan.

Kecamatan Tuminting merupakan salah satu kecamatan yang berada di Kota Manado yang memiliki lingkungan permukiman penduduk dengan lahan terbatas untuk dikembangkan sebagai ruang terbuka hijau (RTH). Dengan keterbatasan lahan pada lingkungan permukiman maka tim IbM hendak mengusulkan pengembangan RTH lingkungan perkotaan melalui penerapan konsep taman vertikal melalui kelompok Karang Taruna di Kecamatan Tuminting yang aktif dan peduli dengan program-program peningkatan lingkungan hijau yang bersih, sehat dan asri.

Tujuan kegiatan pengabdian ini untuk meningkatkan peran serta masyarakat dalam pengembangan Taman Vertikal di Kota Manado sebagai upaya penghijauan pada lahan-lahan terbatas perkotaan. Mengembangkan keterampilan kelompok dalam peningkatan kualitas lingkungan permukiman. Sehingga tercipta tujuan pemberdayaan masyarakat dalam partisipasi pembangunan ruang terbuka hijau perkotaan dapat tercapai melalui pembinaan dan pendampingan penyuluhan dan pelatihan.

\section{Permasalahan Mitra}

Berdasarkan permasalahan di atas maka dapat dirumuskan masalah prioritas 28 yang perlu ditangani oleh kelompok Karang Taruna Kecamatan Tuminting dan pendamping dari perguruan tinggi yaitu: 1) Kurangnya pemahaman masyarakat akan pentingnya pembangunan RTH perkotaan; 2) Kurangnya pengetahuan masyarakat tentang pengembangan konsep taman vertikal di lingkungan permukiman; dan 3) Kurangnya pengetahuan masyarakat dalam pembuatan taman vertikal yang murah, menarik dan indah.

\section{Target dan Luaran}

Target luaran yang ingin dicapai pada pembinaan dan pendampingan kelompok Karang Taruna Kecamatan Tuminting adalah: (1) Melakukan penataan/pembuatan taman vertikal, (2) Meningkatkan partisipasi masyarakat dalam penataan lansekap, (3) Menghasilkan artikel ilmiah yang dapat dipublikasikan pada seminar nasional. Jika kelompok Karang Taruna Kecamatan Tuminting berhasil menerapkan konsep taman vertikal yang melibatkan peran aktif masyarakat dalam pembangunan RTH perkotaan, maka kelompok ini diharapkan menjadi penggerak atau motivator bagi kelompok-kelompok kecamatan lainnya di Kota Manado dalam menerapkan taman-taman vertikal di lingkungan permukiman penduduk dengan lahan-lahan terbatas. Sehingga kualitas lingkungan kota Manado diharapkan semakin tertata sesuai visi Kota Manado yakni menjadikan Manado sebagai Kota Pariwisata Dunia. 


\section{METODE PELAKSANAAN}

Berdasarkan permasalahan kelompok kecamatan maka diperlukan pembinaan dan pendampingan terhadap kelompok tersebut. Pembinaan dan pendampingan yang dilakukan untuk menangani beberapa masalah prioritas yang dapat dilakukan dengan tahapan sebagai berikut.

\section{Penyuluhan}

Penyuluhan dilakukan terhadap anggota kelompok kelurahan dengan tujuan memperluas wawasan pengetahuan kelompok-kelompok tersebut, tentang konsep pengembangan taman vertikal pada lahan terbatas perkotaan. Materi penyuluhan menyangkut Pengembangan Konsep Taman Vertikal di Kota Manado.

\section{Pelatihan}

Setelah dilakukan penyuluhan terhadap anggota kelompok masyarakat, selanjutnya dilakukan pelatihan bagi anggota kelompok. Pelatihan dimaksud antara lain: 1) Taman Vertikal sebagai solusi mengatasi terbatasnya ruang terbuka hijau (RTH); 2) Beberapa Cara Membuat Taman Vertikal; dan 3) Jenis-Jenis Tanaman Yang Digunakan Pada Taman Vertikal.

\section{HASIL DAN PEMBAHASAN}

Manfaat Pelatihan dan Respon

\section{Masyarakat Terhadap Kegiatan IbM}

Peserta kelompok mitra yang hadir pada kegiatan IbM 90\% merasa senang dengan kegiatan pelatihan yang dilakukan oleh tim pengabdian kepada masyarakat Fakultas Teknik Unsrat. Setelah peserta kelompok mitra mengikuti kegiatan pelatihan ini maka respon yang ditunjukkan diantaranya: masyarakat semakin terinspirasi dan bersemangat untuk mengelola sampah-sampah plastik yang banyak dijumpai di pinggiran sungai untuk dijadikan wadah taman vertikal. Kelompok masyarakat yang hadir dalam kegiatan IbM ini dikoordinir oleh kelompok Karang Taruna kecamatan Tuminting yang aktif berkreasi menciptakan program-program berbasis pemberdayaan masyarakat dan lingkungan.

Hasil diskusi tim IbM dan peserta kegiatan Pelatihan Taman Vertikal berlangsung baik dan mencapai sasaran kegiatan. Permasalahan mitra dapat dijawab oleh tim IbM dengan menciptakan inovasi baru dalam penataan RTH di lingkungan permukiman padat penduduk. Masyarakat meresponi dengan baik kegiatan IbM ini dan menyatakan materi yang diberikan belum pernah disosialisasikan sehingga kelompok mitra merasa memperoleh pengetahuan tambahan dalam menciptakan inovasi lingkungan asri dan ramah lingkungan. Melalui sosialisasi pelatihan taman vertikal diharapkan masyarakat dapat memanfaatkan sampah daur ulang menjadi taman yang asri di lingkungan tempat tinggal yang terbatas lahannya. Sehingga perluasan taman vertikal semakin melebar ke lingkungan permukiman sekitarnya yang secara berkesinambungan menciptakan 
masyarakat yang sadar dan peduli terhadap kualitas lingkungan bermukim. Respon lain yang ditunjukkan oleh masyarakat yaitu keinginan menjalin kerjasama dengan pihak institusi unsrat melalui program-program serupa seperti pengembangan hidroponik dengan tanaman-tanaman pangan yang dapat menunjang kebutuhan pangan seharihari masyarakat pinggiran sungai bailang.

\section{Pengertian Tanaman Vertikal}

Taman Vertikal atau taman tegak atau vertical garden adalah tanaman dan elemen taman yang disusun sedemikian rupa pada bidang tegak lurus atau mendekati tegak lurus sebagai taman dalam waktu yang relatif lama. Penataannya memadukan unsur softscape (tanaman) dan unsur hardscape (bebatuan, besi, dan lainlain). Tanaman disusun dalam media tanam tertentu secara permanen sehingga tanaman bisa hidup dan tumbuh secara optimal dalam jangka waktu yang cukup lama pada bidang vertikal. Taman Vertikal dapat diaplikasikan di berbagai dinding bangunan, pagar, tempat parkir, dan dinding lainnya. Bidang-bidang vertikal tersebut terlihat lebih indah dan tidak monoton sebagai dinding keras, tapi lebih berkesan alami. Tanaman disusun dalam media tanam tertentu secara permanen sehingga tanaman bisa hidup dan tumbuh secara optimal dalam jangka waktu yang cukup lama pada bidang vertikal (Budiarto S, 2013). Konsep go green, penghijauan, back to nature, global warming, telah 30 memunculkan elemen tanaman sebagai suatu kebutuhan untuk keseimbangan kehidupan manusia. Sejak isu lingkungan (global warming) semakin meningkatkan efek pulau panas perkotaan (urban heat islands), konsep penghijauan mulai muncul dengan konsep taman vertikal. Kebutuhan ruang terbuka hijau di perkotaan semakin diperlukan dalam era globalisasi saat ini untuk keseimbangan hidup, tetapi keterdesakan kebutuhan akan lahan di perkotaan telah membatasi terciptanya ruang-ruang terbuka hijau yang berfungsi ekologis. Konsep taman vertikal (vertical garden) telah menjawab kebutuhan ruangruang terbuka hijau di lahan sempit.

\section{Pengembangan RTH Dalam Peningkatan Kualitas Lingkungan Permukiman}

$$
\text { Manfaat RTH antara lain }
$$

menyeimbangkan kualitas lingkungan sekitar dengan menciptakan elemen-elemen tanaman sebagai unsur pembentuk iklim mikro atau kenyamanan dan keasrian lingkungan pemukiman. Pemukiman sebagai tempat manusia membangun kehidupannya seharusnya dirancang dengan memperhatikan keseimbangan antara fisik bangunan, alam, dan manusia sebagai penghuni permukiman tersebut. Pengelolaan RTH membutuhkan peran aktif pemerintah secara umum dan masyarakat secara khusus. Keterlibatan masyarakat dalam pembangunan RTH, diharapkan dapat menumbuhkan rasa kepedulian terhadap lingkungan, sehingga eksistensi 
RTH dapat tetap terjaga sehingga upaya untuk membangun kota hijau (green city) yang berwawasan lingkungan dapat tercapai (Moniaga, I 2016).

Peran masyarakat dalam menciptakan RTH merupakan upaya melibatkan masyarakat baik pada tahap perencanaan, pemanfaaatan dan pengelo-laan. Peran masyarakat pada RTH privat meliputi; peningkatan kualitas lingkungan, meningkatkan kualitas permukiman dalam hal penanaman tanaman, menata seoptimal mungkin bidang-bidang vertikal di lingkungan permukiman dengan berbagai jenis tanaman, baik ditanam pada wadah sampah yang terkelola, maupun pada wadah-wadah tanaman vertikal dengan sistim gantung atau dilekatkan pada dinding beton, dan lainnya.

Taman Vertikal banyak dimanfaatkan sebagai solusi untuk mengatasi terbatasnya RTH di lingkungan perkotaan. RTH sangat diperlukan dalam hidup manusia. Tanaman merupakan penghasil oksigen yang dibutuhkan oleh manusia untuk bernafas. Tanaman juga dapat mengurangi panasnya suhu udara di perkotaan. Selain itu tanaman dapat mengatasi masalah polusi udara, polusi tanah, dan polusi kebisingan. Lingkungan permukiman yang padat penduduk dengan penataan taman vertikal yang hijau dan asri dapat menciptakan kualitas kehidupan manusia karena hadirnya tanaman dapat menjadi salah satu cara mengurangi tingkat stress dan depresi (Budiarto S, 2013).

\section{Sistem Pembuatan Taman Vertikal}

Sistem taman vertikal dapat dikembangkan dengan berbagai model, bahan, dan struktur pembuatan seperti; bahan besi, plastik, bambu, kayu, dan lainnya. Penggunaan pot tanaman sebagai wadah tanaman tumbuh juga bermacammacam diantaranya; pot plastik, pot tanah liat, pot bambu, pot plastik, atau pot dari bahan lainnya. Pot tanaman semuanya disusun sedemikian rupa pada bidang vertikal. Berbagai model dan bahan merupakan struktur yang digunakan untuk menegakkan pot-pot tanaman sehingga membentuk pola dan komposisi tanaman yang diinginkan. Pot yang digunakan bisa berbentuk silinder, persegi panjang, atau pot memanjang seperti talang (gutter). Pot diisi dengan media tanam berupa bahan organik maupun anorganik, seperti serbuk kelapa, sekam bakar, peat moss,pasir atau campuran dari beberapa bahan tersebut. Selanjutnya, tanaman ditanam seperti umumnya dalam pot, tetapi disusun sedemikian rupa sehingga secara keseluruhan dalam bidang vertikal tersebut tercipta suatu pola tertentu. Saat ini beberapa produsen sudah membuat suatu pot khusus yang digunakan untuk taman vertikal. Bentuknya dibuat khusus agar masing-masing pot dapat disusun tumpang tindih, saling mengisi dan mengunci pada bidang vertikal. Berbagai bentuk model taman vertikal yang telah dikembangkan saat ini diantaranya; Taman Vertikal Sistem Multipot dengan menempatkan susunan pot di bidang tegak, 
Sistem Kantong (Pocket), Sistem Rambatan, dan Sistem Tebing Bebatuan dan lainnya.

\section{Penerapan Taman Vertikal Pada Lahan}

\section{Terbatas Permukiman Padat Penduduk}
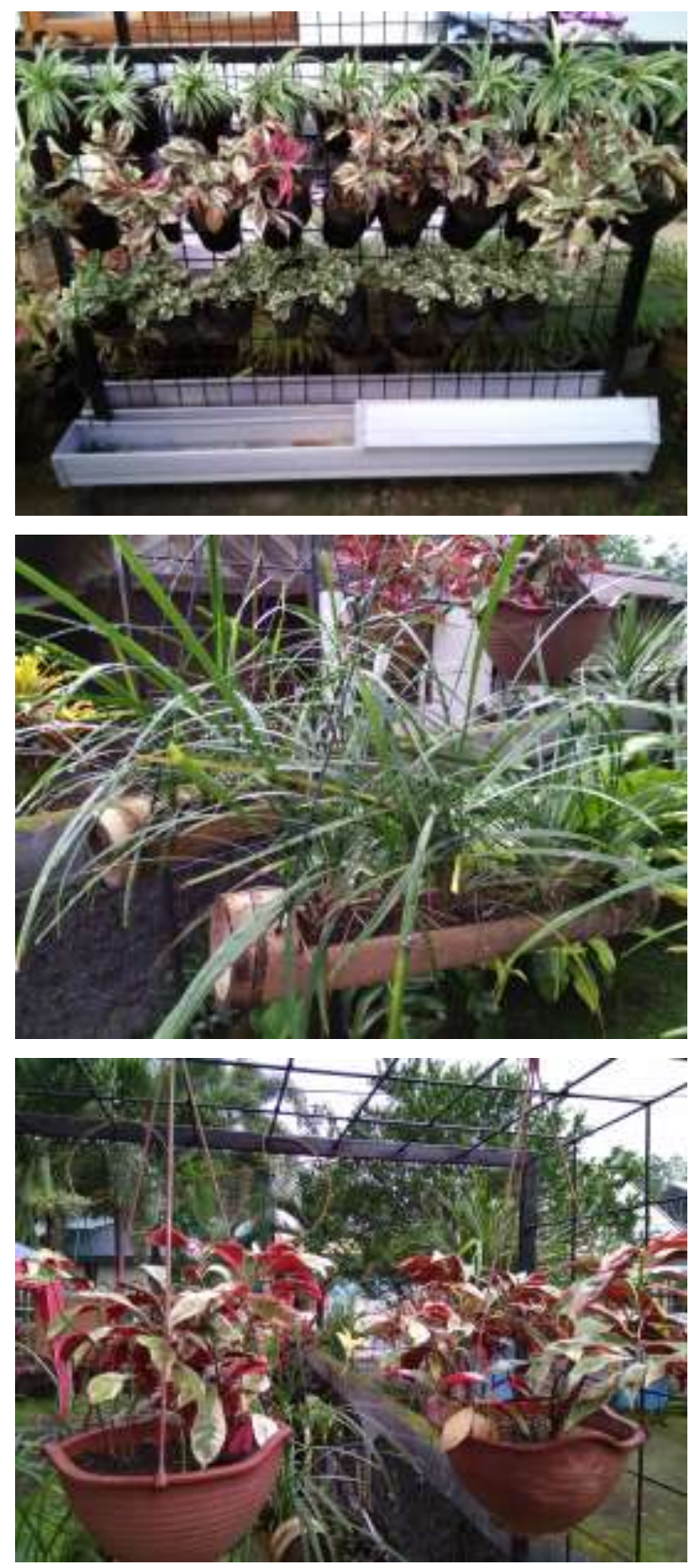

Gambar 1. Berbagai Pot Tanaman Taman Vertikal.

Penerapan Taman Vertikal Pada Lahan Terbatas Permukiman Padat Penduduk kecamatan Tuminting, dilakukan dengan penerapan gabungan berbagai model sistem 32
Taman Vertikal dan berbagai media pot-pot tanaman. Media pot-pot tanaman yang digunakan pada lokasi IbM diantaranya; pot plastik dan bambu. Hal ini bertujuan agar kelompok mitra dapat mengembangkan berbagai alternatif pengembangan media pot yang tersedia di lingkungan sekitar permukiman. Jika masyarakat dapat menjangkau secara ekonomi pot-pot plastik yang telah tersedia di toko-toko tanaman dapat menggunakannya dalam aplikasi taman vertikal, namun jika tidak dapat memanfaatkan barang-barang bekas sampah rumah tangga untuk diolah menjadi pot tanaman yang dapat dikreasikan. Contohnya bahan bekas bambu hasil pembangunan rumah dapat diolah menjadi pot tanaman yang menarik dan indah (gambar 1).

\section{Penggunaan Tanaman Pada Taman}

Vertikal

Penggunaan tanaman pada taman vertikal dipilih tanaman-tanaman tropis yang mudah perawatannya, toleran terhadap iklim tropis (panas dan hujan) dan memiliki nilai estetika dalam pengaturan komposisi taman.

Secara visual tanaman vertikal dapat menciptakan efek keindahan lingkungan. Tanaman-tanaman yang digunakan pada pelatihan taman vertikal diantaranya; tanaman krokot putih, lili paris, sambang darah, dan kucai. 
Jurnal ABDIMAS, Vol. 11, No. 1, April 2018

ISSN: 1979-0953 | e-ISSN: 2598-6066
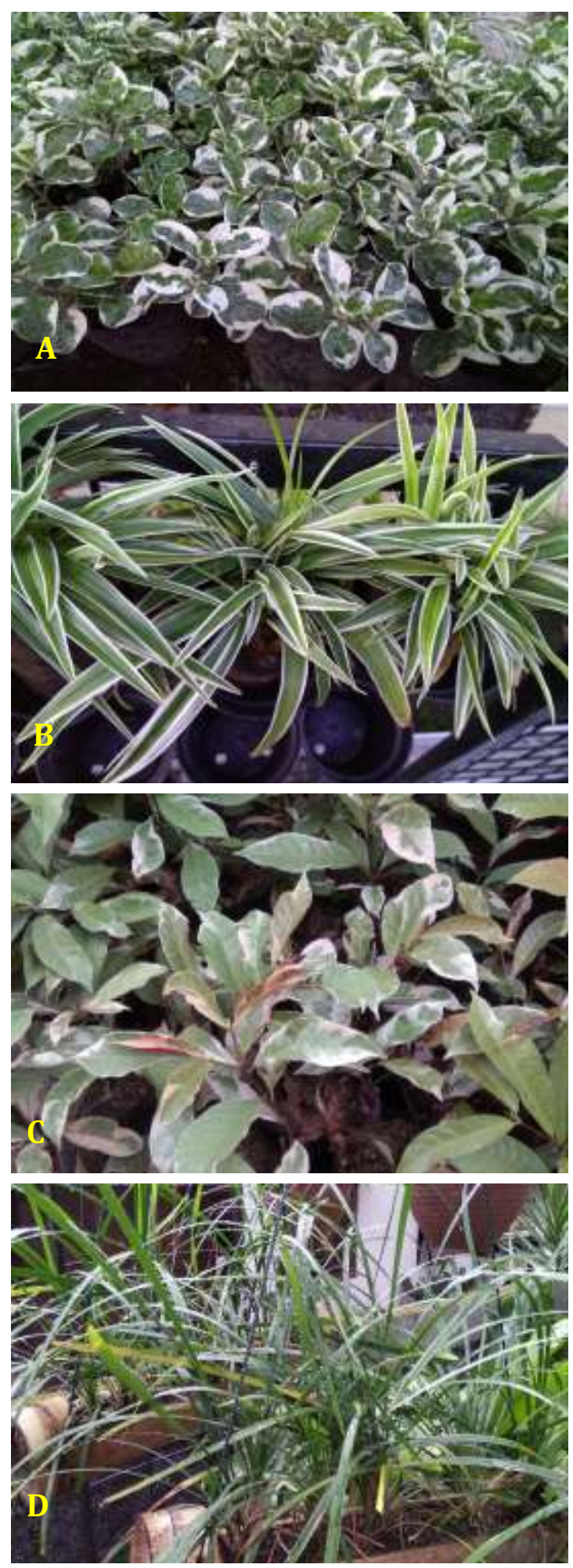

Gambar 2. Tanaman Taman Vertikal di Kecamatan Tuminting: A) Krokot Putih; B) Lili Paris; C) Sambang Darah; dan D) Kucai Hijau.

\section{KESIMPULAN DAN SARAN}

\section{Kesimpulan}

1. Peningkatan Kebutuhan Ruang Terbuka Hijau Privat pada lahan terbatas perkotaan dapat dikembangkan melalui penciptaan taman-taman vertikal dengan memanfaatkan bahan-bahan bekas yang terdapat di lingkungan sekitarnya.

2. Kegiatan-kegiatan pelatihan taman vertikal melalui Ipteks bagi Masyarakat merupakan kegiatan yang membantu pemerintah Kota Manado dalam mewujudkan Visi dan Misi Kota Manado sebagai Kota Pariwisata Dunia melalui penciptaan lingkungan hijau dan asri.

\section{Saran}

Pemerintah Kota Manado perlu bekerjasama dan bermitra dengan perguruan tinggi Unsrat, melalui kegiatan tridharma dosen khususnya bidang pengabdian kepada masyarakat untuk mensosialisasikan program-program pemerintah yang terkait dengan pemberdayaan berbasis lingkungan (PBL-Mapalus).

\section{KEPUSTAKAAN}

Budiarto, S. 2013. Inspirasi Desain dan Cara Membuat Vertical Garden. AgroMedia Pustaka. ISBN 979-006-458-6

Moniaga, I. 2015. Makalah Pengembangan Ruang Terbuka Hijau dipresentasikan kepada Masyarakat Kelurahan Bitungkarangria Kota Manado. November 2015. 
Jurnal ABDIMAS, Vol. 11, No. 1, April 2018

ISSN: 1979-0953 | e-ISSN: 2598-6066 